\title{
UJI KONDUKTIVITAS TERMAL PADA BAHAN MASONITE DENGAN STIM GENERATOR TD 8556
}

\author{
Mumung Kartasasmita ${ }^{1}$ \\ Wahyu Dian Laksanawati ${ }^{2}$ \\ Program Studi Teknik Mesin Fakultas Teknik \\ Universitas Muhammadiyah Prof DR HAMKA ${ }^{1}$ \\ Program Studi Pendidikan Fisika Fakultas Ilmu Keguruan Dan Pendidikan \\ Universitas Muhammadiyah Prof DR HAMKA ${ }^{2}$ \\ Email: mumung_kartasamita@gmail.com
}

\begin{abstract}
Abstrak
Bahan Masonite yaitu suatu bahan jenis hardboard yang ditemukan oleh William H. Mason. Proses pembuatannya dilakukan dengan metode mason menggunakan kayu chip, mengurainya menjadi serat panjang dengan uap lalu membentuknya ke papan. Papan tersebut kemudian diletakkan dan dipanaskan untuk membentuk tampilan akhir papan. Dalam hal ini tidak digunakan lem atau materi lain yang ditambahkan. Serat lama memberikan Masonite tinggi akan kekuatan lentur, kekuatan tarik, kepadatan dan stabilitas. Masonite berbeda dengan panel kayu komposit yang diproduksi menggunakan formalin berbasis resin untuk mengikat serat, Masonite dibuat dengan bahan alami saja sehingga produknya ramah lingkungan. Sebagaimana bahan alami, Masonite akan membusuk dari waktu ke waktu. Bahan Masonite ini memiliki koefisien konduktivitas termal 1,13 x $10^{-4}$ cal.cm $/ \mathrm{cm}^{2}$ sec. ${ }^{0}$ C.Percobaan konduktivitas termal bahan Masonite dilakukan dengan melelehkan es di atas stim generator melalui bahan Masonite sebagai alas silinder es sehingga diperoleh massa lelehan es per waktu pemanasan. Dari hasil percobaan didapat konduktivitas termal bahan Masonite sebesar $1,14 \times 10^{-4}$ cal.cm $/ \mathrm{cm}^{2}$ sec. ${ }^{0} \mathrm{C}$. hasil ini menunjukkan bahwa bahan Masonite adalah bahan isolator.
\end{abstract}

Kata kunci: Konduktivitas Termal, Generator.

\section{PENDAHULUAN}

Dalam bidang konstruksi bangunan, selalu diinginkan adanya suatu bahan yang ringan tetapi kokoh dan tahan terhadap perubahan temperatur, namun dibalik keinginan itu ilmuwan melakukan riset untuk menemukan bahan yang tepat digunakan di masa kini. Inovasiinovasi yang dilakukan ilmuwan 
Friska. C., Nyoto. S. - Pengembangan LKS Materi...

untuk menemukan suatu bahan yang efisisen sudah tak terhitung nilainya mulai dari yang diterapkan oleh industri dan dipasarkan maupun yang tidak.

Salah satu inovasi yang dilakukan adalah pada bahan untuk membuat daun pintu, seperti kita ketahui masyarakat menginginkan daun pintu yang ringan sehingga tidak membebani engsel pintu tetapi kokoh, tahan terhadap cuaca, murah dibandigkan dengan kayu jati, mahoni, dll., dan tentunya yang ramah lingkungan dalam produksi-nya maupun penggunaannya. Maka dipilihlah bahan Masonite yaitu suatu bahan jenis hardboard yang ditemukan oleh William H. Mason. Proses pembuatannya dilakukan dengan metode mason menggunakan kayu chip, mengurainya menjadi serat panjang dengan uap lalu membentuknya ke papan. Papan tersebut kemudian diletakkan dan dipanaskan untuk membentuk tampilan akhir papan. Dalam hal ini tidak digunakan lem atau materi lain yang ditambahkan. Serat lama memberikan Masonite tinggi akan kekuatan lentur, kekuatan tarik, kepadatan dan stabilitas. Masonite berbeda dengan panel kayu komposit yang diproduksi menggunakan formalin berbasis resin untuk mengikat serat, Masonite dibuat dengan bahan alami saja sehingga produknya ramah lingkungan. Sebagaimana bahan alami, Masonite akan membusuk dari waktu ke waktu. Bahan Masonite ini memiliki koefisien konduktivitas termal 1,13 x $10^{-4}$ cal.cm $/ \mathrm{cm}^{2}$ sec. ${ }^{0} \mathrm{C}$

Untuk mengetahui konduktivitas termal bahan Masonite ini dilakukan pengujian dengan alat Stim Generator TD-8556, pengujian ini bertujuan untuk mengukur konduktivitas termal bahan/material serta menentukan tipe material sampel yang digunakan apakah konduktor atau isolator.

Menurut Giancoli

(2001) Konduktivitas termal $(k)$, adalah suatu besaran intensif bahan yang menunjukkan kemampuannya untuk menghantarkan panas. Konduksi termal adalah suatu fenomena transport di mana perbedaan temperatur menyebabkan transfer energi termal dari satu daerah benda panas ke daerah yang sama 
Friska. C., Nyoto. S. - Pengembangan LKS Materi...

pada temperatur yang lebih rendah. Panas yang di transfer dari satu titik ke titik lain melalui salahsatu dari tiga metoda yaitu konduksi, konveksi, dan radiasi. Konduktivitas termal $=$ laju aliran panas $\times$ jarak $/($ luas $\times$ perbedaan suhu )

$$
k=\frac{Q}{t} \times \frac{L}{A \times \Delta T}
$$

Besaran ini didefinisikan sebagai panas, Q, yang dihantarkan selama waktu t melaui ketebalan $\mathrm{L}$, dengan arah normal ke permukaan dengan luas A yang disebabkan oleh perbedaan suhu $\Delta \mathrm{T}$ dalam kondisi tunak dan jika perpindahan panas hanya tergantung dengan perbedaan suhu tersebut.

Menurut Tipler (2001) Konduktor adalah kemampuan suatu bahan untuk menghantarkan suatu energi. Dalam hal ini sifat konduktor bahan dapat dibagi kedalam dua sifat yaitu konduktor listrik dan konduktor panas, kedua sifat ini dijelaskan sebagai berikut :

$\begin{array}{rrr} & \text { Konduktor listrik adalah zat } \\ \text { yang } & \text { dapat menghantarkan }\end{array}$
arus listrik, baik berupa zat padat, cair atau gas. Karena sifatnya yang konduktif maka disebut konduktor.
Konduktor yang baik adalah yang memiliki tahanan jenis yang kecil. Logam yang bersifat konduktif misalnya

emas, perak, tembaga, alumunium, zin $\mathrm{k}$, besi berturut-turut memiliki tahanan jenis semakin besar. Jadi sebagai penghantar emas adalah sangat baik, tetapi karena sangat mahal harganya, maka secara ekonomis tembaga dan alumunium paling banyak digunakan.

Konduksi panas atau konduksi termal adalah perambatan panas tanpa disertai perpindahan bagian-bagian zat perantaranya. Perambatan ini biasanya terjadi pada benda padat. Kalor mengalir pada konduktor dari bagian yang bersuhu tinggi ke bagian yang bersuhu rendah. Menurut Charles (1980), pada bahan konduktor, suhu akan terdistribusi sepanjang permukaan konduktor sehingga membuat lintasan untuk mengalirkan panas dari tempat dengan jumlah panas lebih banyak(suhu tinggi) ke tempat dengan jumlah panas lebih sedikit (suhu rendah). Kuat perambatan panas yang melewati konduktor bergantung pada kemiringan pembagian suhu 
Friska. C., Nyoto. S. - Pengembangan LKS Materi...

sepanjang konduktor sesuai hukum fourier :

$$
q=-k \frac{d T x}{d x}
$$

Isolator panas adalah suatu bahan yang tidak bisa atau sulit menghantarkan panas. Biasanya bahan isolator bersifat non logam, bahan banyak digunakan untuk menghambat aliran panas misalnya pada pegangan panci ataupun pada peralatan panas lainnya. Contoh bahan isolator yang baik misalnya karet,kayu,plastik,dll.

Bahan masonite seperti pada gambar 1 yaitu suatu bahan jenis hardboard yang ditemukan oleh William H. Mason. Proses pembuatannya dilakukan dengan metode mason menggunakan kayu chip, mengurainya menjadi serat panjang dengan uap lalu membentuknya ke papan. Papan tersebut kemudian diletakkan dan dipanaskan untuk membentuk tampilan akhir papan. Dalam hal ini tidak digunakan lem atau materi lain yang ditambahkan. Serat lama memberikan Masonite tinggi akan kekuatan lentur, kekuatan tarik, kepadatan dan stabilitas. Masonite berbeda dengan panel kayu komposit yang diproduksi menggunakan formalin berbasis resin untuk mengikat serat, Masonite dibuat dengan bahan alami saja sehingga produknya ramah lingkungan. Nilai konduktivitas termal bahan Masonite $1,13 \times 10^{-4} \mathrm{cal} . \mathrm{cm} / \mathrm{cm}^{2} \cdot \mathrm{sec}^{0} \mathrm{C}$

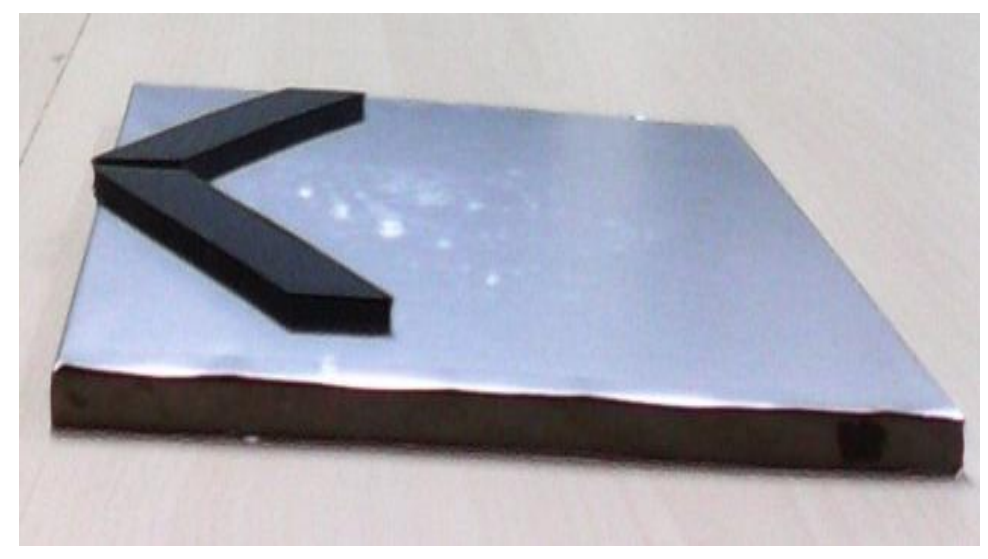

Gambar 1. Bahan Masonite yang diselubungi Alumunium Foil 
Stim generator model TD-8556A adalah sumber efisien dari stim dan pemanas air untuk laboratorium pembelajaran fisika. Tangki yang berisi satu liter air dipanaskan secara elektik dengan daya keluaran sampai 400 watt. Bahaya dari panas berlebih dapat dikurangi dengan thermal cirkuit breaker yang tidak dihubungkan ke daya apabila air di dalamnya telah mengering.

Panas dapat berpindah melalui tiga metode : konduksi, konveksi dan radiasi. Setiap metode dapat dianalisa dan setiap hasilnya memiliki hubungan matematik yang spesifik. Peralatan konduktivitas termal TD8556 tersedia untuk menyelidiki ratarata konduksi termal melalui lima material yang digunakan pada konstruksi bangunan.

Persamaan memberikan jumlah kalor terkonduksi melalui material ditunjukkan oleh:

$$
\Delta Q=k A \Delta T \Delta t / h
$$

Nilai $k$ (konduktivitas termal) suatu bahan berfungsi untuk mengidentifikasi bahan apakah bahan tersebut sebagai penghantar panas yang baik atau buruk. Dalam aplikasinya, dengan diketahuinya nilai $k$ akan memudahkan para pekerja bangunan dan arsitek maupun pemilik rumah dalam memilih bahan yang tepat bagi propertinya.

Tidak selamanya nilai $k$ yang kecil pada suatu bahan akan menjadikan bahan tersebut sebagai pilihan yang baik untuk properti. Pada saat musim salju,panas sulit sekali terkonduksi oleh karena itu diperlukan bahan properti dengan $\mathrm{k}$ yang lebih besar. Maka dalam pemilihan bahan, ada tiga faktor sebagai pertimbangan yaitu luas permukaan, ketebalan, dan perbedaan temperatur.

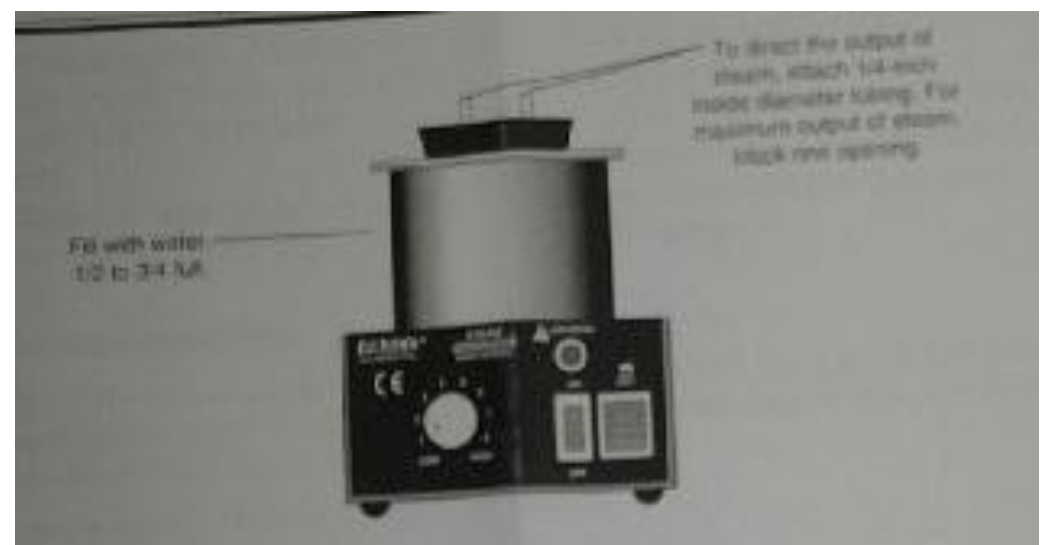


Friska. C., Nyoto. S. - Pengembangan LKS Materi...

\section{Gambar 2. Stim Generator}

Teknik untuk mengukur mengumpulkan air dari lelehan es. konduktivitas termal diterangkan Lelehan es rata-rata 1 gram per 80 dengan jelas berikut ini. Selembar kalori( kalor laten dari lebur es).

papan material yang sedang diuji, Dimana besaran panjang dalam dijepit antara bagian stim yang diberi sentimeter, massa dalam gram dan suhu konstan $100^{\circ} \mathrm{c}$, dan balok es waktu dalam sekon.

dengan temperature $0^{0} \mathrm{c}$. Terjadi Peralatan konduktivitas termal perbedaan temperature tetap sebasar ditunjukkan dalam gambar 3, terdiri $100^{\circ} \mathrm{c}$ diantara permukaan material. dari Penyangga(base).

Hantaran panas dapat diukur dengan

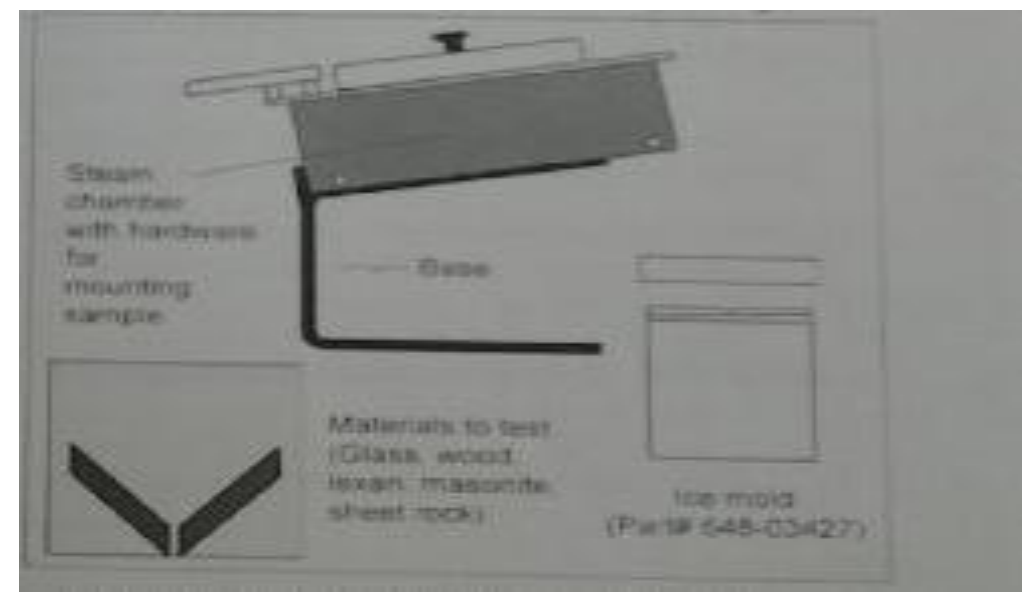

Gambar 3. Perangkat konduktivitas termal

\section{METODE PENELITIAN}

Tujuan dari penelitian ini adalah untuk mengetahui konduktivitas termal bahan Masonite setelah diuji dengan Stim Generator TD-8556.

Metode penelitian yang digunakan adalah metode eksperimen. Menurut Sudjana (2005) Eksperimen atau eksperimen nyata merupakan eksperimen yang memungkinkan peneliti melakukan pengontrolan penuh terhadap variabel dan kondisi eksperimen.

Teknik Pengambilan Data 
Friska. C., Nyoto. S. - Pengembangan LKS Materi...

Kondiktivitas termal suatu yang dibuat dengan serat kayu chip bahan adalah kemampuan bahan yang dipanaskan dengan uap panas tersebut untuk menghantarkan panas, sehingga merekat menjadi papan konduktivitas termal dinotasikan tanpa dipanaskan. Setelah diukur dengan $k$ yang. Untuk mengukur dengan alat stim generator, akan konduktivitas termal suatu bahan diketahui nilai $k$ nya, sehingga kita digunakan alat yang disebut Stim bisa mengidentifikasi apakah bahan Generator yang sistem kerjanya Masonite ini termasuk konduktor atau memberikan perbedaan suhu antara isolator setelah itu dibandingakan dua sisi sampel. Dalam penelitian ini dengan literatur konduktivitas yang dipakai adalah sampel bahan termalnya apakah sama atau tidak.

Masonite yaitu bahan hard board

Gambar 1. Diagram Alur Penelitian

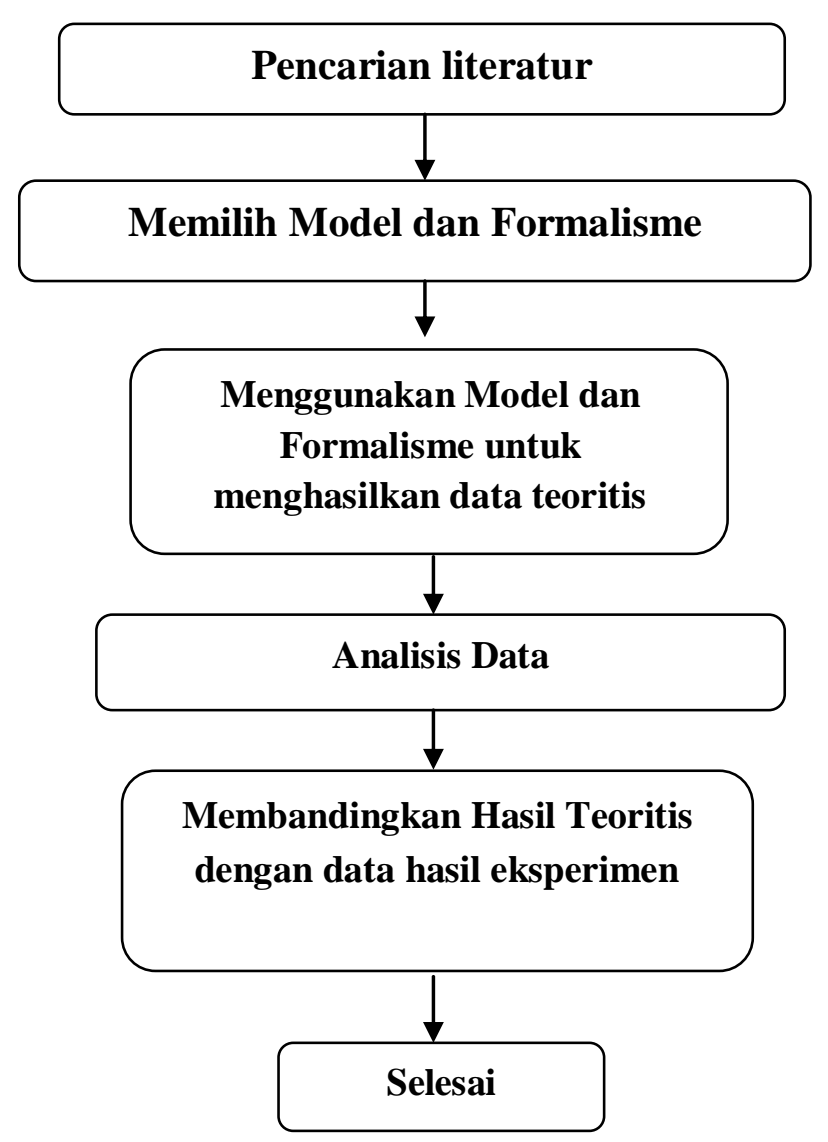


Friska. C., Nyoto. S. - Pengembangan LKS Materi...

\section{HASIL DAN PEMBAHASAN}

Tabel 1 Hasil Percobaan konduktivitas Termal

\begin{tabular}{|l|l|}
\hline $\mathrm{h}$ & $0,46 \mathrm{~cm}$ \\
\hline $\mathrm{d}_{1}$ & $6,3 \mathrm{~cm}$ \\
\hline $\mathrm{d}_{2}$ & $5,4 \mathrm{~cm}$ \\
\hline $\mathrm{t}_{\mathrm{a}}$ & $600 \mathrm{~s}$ \\
\hline $\mathrm{m}_{\mathrm{wa}}$ & $31 \mathrm{gr}$ \\
\hline $\mathrm{t}$ & $600 \mathrm{~s}$ \\
\hline $\mathrm{m}_{\mathrm{w}}$ & $36 \mathrm{gr}$ \\
\hline $\mathrm{d}_{\mathrm{avg}}$ & $5,85 \mathrm{~cm}$ \\
\hline$A$ & $26,86 \mathrm{~cm}^{2}$ \\
\hline $\mathrm{R}_{\mathrm{a}}$ & $5,17 \times 10^{-2} \mathrm{gr} / \mathrm{sec}$ \\
\hline $\mathrm{R}^{-2}$ & $6,0 \times 10^{-2} \mathrm{gr} / \mathrm{sec}$ \\
\hline $\mathrm{R}_{0}$ & $0,83 \times 10^{-2} \mathrm{gr} / \mathrm{sec}$ \\
\hline
\end{tabular}

Dari Tabel 1 untuk menghitung konduktivitas termal bahan Masonite digunakan rumusan matematis sebagai berikut :

$$
\begin{gathered}
k=\frac{\Delta Q \cdot h}{A \cdot \Delta T \cdot \Delta t} \\
k=\frac{\left(R_{0}\right)(80 \mathrm{cal} / \mathrm{gr})(h)}{(A)(\Delta T)}
\end{gathered}
$$

Dengan kalor lebur es $80 \mathrm{cal} / \mathrm{gr}$,maka, $k=\frac{\left(0,83 \times 10^{-2} \mathrm{gr} / \mathrm{sec}\right)(80 \mathrm{cal} / \mathrm{gr})(0,46 \mathrm{~cm})}{\left(26,86 \mathrm{~cm}^{2}\right)\left(100^{0} \mathrm{C}\right)}$

$$
k=\frac{0,306}{2686} \frac{\mathrm{cal} \cdot \mathrm{cm}}{\mathrm{cm}^{2} \cdot \mathrm{sec}^{0} \mathrm{C}}
$$

$$
\begin{gathered}
k=\frac{0,306}{2686} \frac{\mathrm{cal} \cdot \mathrm{cm}}{\mathrm{cm}^{2} \cdot \mathrm{sec}^{0} \mathrm{C}} \\
k=1,14 \times 10^{-4} \frac{\mathrm{cal} \cdot \mathrm{cm}}{\mathrm{cm}^{2} \cdot \mathrm{sec}^{0} \mathrm{C}}
\end{gathered}
$$

Sehingga diperoleh konduktivitas termal bahan Masonite sebesar 1,14 x $10^{-4} \mathrm{cal} . \mathrm{cm} / \mathrm{cm}^{2}$ sec. ${ }^{0} \mathrm{C}$ Lalu dibuat data tabel :

Tabel 2. Konduktivitas Termal pada berbagai $\mathrm{R}$

\begin{tabular}{|l|l|l|}
\hline No. & \multicolumn{1}{|c|}{$\mathrm{R}_{0}$} & \multicolumn{1}{|c|}{$\mathrm{K}$} \\
\hline 1. & 0.0083 & 0.000114 \\
\hline 2. & 0.0082 & 0.000112 \\
\hline 3. & 0.00825 & 0.000113 \\
\hline
\end{tabular}


Friska. C., Nyoto. S. - Pengembangan LKS Materi...

\begin{tabular}{|l|l|l|}
\hline 4. & 0.00815 & 0.000117 \\
\hline 6. & 0.00817 & 0.000119 \\
\hline 5. & 0.00819 & 0.000112 \\
\hline 7. & 0.00823 & 0.000113 \\
\hline 8. & 0.00828 & 0.000113 \\
\hline 10. & 0.00831 & 0.000114 \\
\hline 11. & 0.00833 & 0.000114 \\
\hline
\end{tabular}

\section{PENUTUP}

\section{Kesimpulan}

Berdasarkan hasil percobaan didapat nilai konduktivitas termal bahan Masonite sebesar 1,14 × $10^{-4}$ cal.cm $/ \mathrm{cm}^{2}$ sec. ${ }^{0} \mathrm{C}$ yang mendekati nilai literatur sebesar $1,13 \times 10^{-4}$ cal.cm $/ \mathrm{cm}^{2}$ sec. ${ }^{0} \mathrm{C}$ hal ini menunjukkan bahwa bahan Masonite termasuk ke dalam bahan isolator. Penelitian ini memerlukan ketelitian dalam melakukan percobaan supaya didapat nilai konduktivitas yang mendekati nilai literatur. Diperlukan kesabaran untuk melakukan percobaan dengan teliti dan berulang-ulang kali. Dan sediakan bahan habis pakai yang cukup mislanya es yang berbentuk silinder supaya lebih efisien waktu.

\section{DAFTAR PUSTAKA}

C. Giancoli, Douglas. Fisika Jilid 1 Edisi ke 5. 2001. Jakarta : Erlangga.

Paul A, Tipler. Fisika untuk Sains dan Teknik Jilid 1 (edisi ketiga). 2001. Jakarta : Erlangga.

Charles Kittel, Herbert Kroemer. Thermal Physics. 1980 . WIT Freman : San Fransisco

Sudjana. Metoda Statistika. 2005. Bandung:Tarsito 